\title{
OTRO EPISODIO DE COMERCIO ARTÍSTICO. ESCULTURAS ANDALUZAS EN TENERIFE A PRINCIPIOS DEL SIGLO XIX
}

\author{
ANOTHER EPISODE OF ART TRADE. SCULPTURES \\ FROM ANDALUSIA IN TENERIFE DURING THE EARLY \\ NINETEENTH CENTURY
}

\author{
Juan Alejandro Lorenzo Lima \\ Universidad Europea de Canarias. España \\ juanalejandro.lorenzo@universidadeuropea.es
}

\begin{abstract}
En este artículo se estudian de forma pormenorizada cuatro esculturas de Tenerife que fueron contratadas en Andalucía entre 1800 y 1816, gracias al contacto de sus comitentes con agentes y compañías que comerciaban en Cádiz y Sevilla. La casuística tan diferente que describe cada encargo obliga a exponer su coyuntura histórica y artística de forma individualizada, resaltando por igual valores creativos y devocionales. Se propone la atribución de algunas obras a los imagineros Doménico Giscardi (1725-1805) y Juan de Astorga (1777-1849).

Palabras clave: escultura, comercio artístico, Neoclasicismo, Sevilla, Cádiz, Doménico Giscardi, Juan de Astorga.
\end{abstract}

In this essay we study four sculptures of Tenerife that were acquired in Andalusia between 1800 and 1816, through the contact with companies and agents who resided in Cadiz and Seville. Each religious sculpture has its own casuistry and it requires a commentary on its historical and artistic value individually, highlighting devotional and creative circumstances. We propose the attribution of them to the artists Doménico Giscardi (1725-1805) and Juan de Astorga (1777-1849).

Keywords: sculpture, art trade, Neoclassicism, Sevilla, Cadiz, Domenico Giscardi, Juan de Astorga.

El envío de imaginería andaluza a las Islas Canarias fue una práctica común durante la época Moderna y, como tal, no trascendió a dicho periodo o etapa histórica ${ }^{1}$. Al tiempo que tuvo lugar la crisis del Antiguo Régimen y el inicio de la

${ }^{1}$ Cfr. AA.VV.: Historia cultural del arte en Canarias. Islas Canarias, 2008-2010. 
contemporaneidad la adquisición de efigies foráneas decayó entre los comitentes o promotores locales, hasta el punto de que las obras llegadas al Archipiélago durante ese tiempo pueden cuantificarse y estudiarse sin dificultad. De este modo, lo que antes era habitual y cotidiano se convertiría en algo excepcional, capaz, incluso, de no ser bien entendido entre quienes promovieron el ajuste, la ejecución de los pocos trabajos contratados, su traslado hasta los puertos insulares desde la bahía de Cádiz, y el pago de todo ello con dinero en efectivo o letras de cambio. No debe olvidarse que a finales del siglo XVIII los imagineros sevillanos vivieron una etapa compleja y errática, hasta el punto de que interpretaciones razonadas de su evolución hacen coincidir tal coyuntura con el fin de la escuela escultórica ${ }^{2}$; y para el contexto gaditano, el otro foco al que recurrieron los isleños con el fin de satisfacer encargos muy diversos, el panorama no es distinto si atendemos a la desaparición paulatina de sus talleres en un contexto donde primaba el influjo genovés, una dependencia creciente hacia el trabajo de maestros foráneos y el cese de su propia idiosincrasia ${ }^{3}$.

El estancamiento de las importaciones andaluzas no fue un fenómeno espontáneo y resulta extrapolable a lo sucedido de forma coetánea con mercados que los canarios frecuentaban desde el siglo XVI, ya que, a diferencia de la dinámica vivida en fecha previa, a principios del Ochocientos no arribaron tantas obras desde Génova o unas colonias de América cada vez más autosuficientes, que empezaban a luchar por su independencia con el apoyo de intelectuales y militares que en algunos casos tenían sangre isleña ${ }^{4}$. En la decadencia de este episodio del comercio artístico influyó también la fama ganada por José Luján Pérez (1756-1815) y Fernando Estévez (1788-1854), quienes, como "avezados escultores de la patria", acomodaron las directrices del gusto moderno y esculpieron obras acordes a la realidad local. De ahí que sus talleres acapararan los encargos que se produjeron desde diversas islas en un tiempo verdaderamente complejo para todo, primero por las reformas que clérigos ilustrados alentaban en torno a la religiosidad popular y luego en el seno de la propia Iglesia ${ }^{5}$.

${ }^{2}$ RECIO MIR, Álvaro: "La escultura sevillana, la Academia de San Fernando y el ocaso de la Escuela", Academia. Boletín de la Real Academia de Bellas Artes de San Fernando, 104-105, 2007, pp. 133-156.

3 Cfr. DE LA BANDA Y VARGAS, Antonio: "Panorámica de la escultura gaditana del Academicismo al Romanticismo", Anales de la Real Academia de Bellas Artes de Cádiz, 4, 1986, pp. 9-15.

${ }^{4}$ AMADOR MARRERO, Pablo F.: El legado indiano en las islas de la Fortuna. Escultura americana en Canarias. México, en prensa.

${ }^{5}$ Cfr. AA.VV: Luján Pérez y su tiempo [catálogo de la exposición homónima]. Islas Canarias, 2007. 
Sin obviar ese contexto y las ventajas de todo tipo que el envío de plata, tejidos y loza gaditana revelaba principios del siglo $\mathrm{XIX}^{6}$, en los epígrafes que siguen prestamos atención al encargo de cuatro esculturas con atractivo en el medio insular y andaluz por la proyección atlántica de los maestros a quienes son atribuidas ahora: una talla de San José con el Niño que fray Antonio Perdomo anheló desde 1786 para presidir un retablo en el templo agustino de Icod, una pareja de santos hospitalarios que a partir de 1804 incentivaron en lo devocional y lo caritativo a la feligresía de La Orotava y, muy especialmente, la Inmaculada que sor Isabel Manuel del Castillo hizo traer de Sevilla en 1819 para la iglesia de su convento en Garachico. El encargo de todas ellas no puede estudiarse bajo los mismos parámetros ni entenderse sin los afanes piadosos que manifestaron sus comitentes, pero, en mayor o menor medida, describen también una casuística que posibilita el análisis y la enumeración de modismos que el gusto neoclásico impuso a la imaginería tradicional o de estilo tardobarroco.

\section{UN SAN JOSÉ PARA EL CONVENTO AGUSTINO DE ICOD}

El encargo de "una efigie del glorioso patriarca San José con el Niño Jesús en sus brazos" guarda relación con la trayectoria vital de fray Antonio de San Agustín Perdomo y, por consiguiente, con devociones familiares y con el convento icodense de San Sebastián, donde profesó en 1763 y desarrollaría luego una actividad meritoria como sacristán, lector de coro, responsable del cobro de tributos y finalmente prior (Figura 1). Un estudio previo de Rodríguez Morales describió esa coyuntura, señalando que los vínculos de sus padres con la comunidad agustina alentaron la temprana vocación de fray Antonio. En el testamento que Lucía Pérez Domínguez, su madre, dictaba en 1771 impuso la celebración de varias misas en el altar ya existente de San José, quizá parte de un retablo construido en fecha previa que el pintor Cristóbal Afonso (1742-1797) pudo decorar con arquitecturas fingidas, repertorios florales y motivos de aliento rococó en torno a ese año. Suyo podría ser también el retrato de dicho fraile que cuelga en el presbiterio de la misma iglesia de San Agustín, con inscripción de 1797 para perpetuar la

${ }^{6}$ FRAGA GONZÁLEZ, María del Carmen: "La casa comercial Cólogan y las adquisiciones artísticas en torno a 1800", en Actas del XII Coloquio de Historia Canario-Americana (1996). Las Palmas de Gran Canaria, 1998, t. II, pp. 203-218; PÉREZ MORERA, Jesús: "Platería en Canarias. Siglos XVI-XIX", en Arte en Canarias [siglos $X V$-XIX]. Una mirada retrospectiva [catálogo de la exposición homónima]. Islas Canarias, 2001, t. I, pp. 247-248; y PÉREZ MORERA, Jesús: "El arte de la seda: el tejido litúrgico en Canarias. Los ornamentos de la Catedral de La Laguna", Revista de Historia Canaria, 184, 2002, pp. 310-312. 
memoria de quien, como recordaron luego sus compañeros del claustro, se manifestó siempre "amantísimo del culto divino y de los aumentos de este convento"

Varias circunstancias avalan su determinación a la hora de importar una talla de San José para el retablo erigido en el templo, aunque ignoramos si esa escultura reemplazaría a una previa ${ }^{8}$. Así lo delata su vínculo con agentes comerciales que operaban en el norte de Tenerife como Tomás y Bernardo Cólogan, avecinados al igual que la empresa o casa de comercio que rigieron en el Puerto de la Cruz. Ahora sabemos que el trato de dicho religioso con los hermanos Cólogan se remonta a la década de 1770 y fue consecuencia de negocios iniciados por su padre el capitán Pedro Perdomo de Bethencourt, ya que, por ejemplo, en septiembre de 1780 fray Antonio pedía a Tomás Cólogan que solventara la deuda dejada por él en su establecimiento9; y años más tarde, recurrió a ellos para que tramitasen el encargo de enseres y obras de arte con los que "adelantar el convento que tanto le debe" 10 .

Una misiva firmada en Icod en diciembre de 1786 advierte sobre su mediación como promotor artístico y el deseo que tuvo de adquirir la citada efigie de San José. Aunque en dicha carta menciona la venta de pipas de vino, resultan de mayor interés los comentarios inéditos sobre una cruz de mármol que quiso erigir en las inmediaciones del convento y responder con ello a una voluntad del ya difunto Cristóbal Hernández. Declaraba entonces a Bernardo Cólogan que tenía en su poder los 80 pesos en que evaluaron el costo con anterioridad, por lo que pedía noticias sobre el encargo para no hacerlo por segunda vez respetando el presupuesto asignado y la condición de que tuviera al pie la leyenda "Diola $D^{n}$ Christobal Hernandes al conv ${ }^{\text {to }}$ Agustino" ${ }^{11}$. No conocemos el paradero de esa obra, el aspecto que mostraba a finales del siglo XVIII ni cuál fue su ubicación definitiva después de haber sido labrada en Cádiz o Génova, ya que en carta remitida a los Cólogan durante la primavera de 1792 fray Antonio expresó su deseo de emplazarla junto a la iglesia de San Sebastián. Para ello relataba que Hernández

${ }^{7}$ RODRÍGUEZ MORALES, Carlos: "El icodense fray Antonio de San Agustín Perdomo y el comercio artístico de la Casa Cólogan en torno a 1800", Semana Santa. Revista del patrimonio histórico-religioso de Ycod, 2003, pp. 25-32.

${ }^{8}$ No hay constancia de ella ni de otros cultos tributados a este santo en el complejo conventual. RODRÍGUEZ MORALES, Carlos: Los conventos agustinos de Canarias. Arte y religiosidad en la sociedad insular de la época Moderna [tesis doctoral, inédita]. La Laguna, 2011, t. I, pp. 127-145.

9 Archivo Histórico Provincial de Tenerife (AHPT): Archivo Zárate Cólogan (AZC). Correspondencia. Sign. 0789/08. Se conservan otras cartas firmadas por Lucía Domínguez Perdomo en Icod durante la década de 1760. Cfr. AHPT: AZC. Correspondencia. Sign. 0564/35; 0561/56; 0579/15, 25, 34; 0590/34; 0592/77; 0607/28, 31, 64; 0608/16; 0627/14, 28, 67; 0628/54; 0633/47, 0644/69; 064/776, 0735/64; 0828/82.

${ }^{10}$ RODRÍGUEZ MORALES, Carlos: "El icodense...”, op. cit., pp. 25-27.

11 AHPT: AZC. Correspondencia. Sign. 0911/02. 
tuvo intención de "colocarla en el centro de dicha plaza y parecerle mejor por no estar al peligro de los muchachos [...], por ser una pieza delicada". La mediación de los Cólogan en este encargo se recordó nuevamente en 1796, puesto que en otra misiva de septiembre de ese año el fraile declaraba deberles parte de su costo ${ }^{12}$.

Antes de 1786 fray Antonio había gestionado la contratación de una efigie de San José a través de los Cólogan, quizá para perpetuar alguna manda o voluntad de sus familiares que nos resulta desconocida. En la misma carta de diciembre refiere el deseo de que por segunda vez preguntaran sobre "el precio que pide el escultor por una imagen de cuerpo natural de talla y su Niño desnudo en los brazos, para, si conviene, mandar por ella"13. Esta cita desvela que el encargo es anterior a 1801 y que de forma inusual se dilató en el tiempo, ya que entre esa noticia que conocemos ahora y el envío de la escultura median quince años. En todo caso, el propio fray Antonio aclara en nota marginal de su misiva que la primera encomienda del santo "se hizo [...] con las de mi compadre Fajardo y [la] pila", referencia enigmática que tiene una explicación lógica. Su compadre Fajardo podría identificarse con Miguel Fajardo o Salvador Hernández Fajardo, vecinos de Icod que desde la década de 1760 alentaron transacciones comerciales e intercambio epistolar con los Cólogan ${ }^{14}$; y en lo concerniente a la pila, suponemos que su cita guarda relación con el envío de una pila benditera de mármol en diversos colores que la iglesia agustina de Icod conserva al uso, junto al retablo de San Vicente Ferrer (Figura 3). Se le ha atribuido origen genovés ${ }^{15}$ y su inscripción aclara que fue costeada por Juan Gutiérrez Delgado, patrono de dicho altar que falleció en $1785^{16}$. Sin embargo, no debe descartarse la posibilidad de que su comentario refiera el encargo de otra pila de mármol blanco que existió en el mismo convento, conservada ahora en la vecina parroquia de San Marcos (Figura 3). En el ajuste de la última medió también fray Antonio, puesto que en carta escrita a los Cólogan durante el verano de 1796 comunicaba el deseo de que al pie tuviese una inscripción para identificar a su comitente: Antonio José Madero, cercano también a la comunidad de frailes agustinos que él representaba ${ }^{17}$.

\footnotetext{
12 RODRÍGUEZ MORALES, Carlos: “El icodense...”, op. cit., p. 27.

13 AHPT: AZC. Correspondencia. Sign. 0911/02.

${ }^{14}$ Cfr. AHPT: AZC. Correspondencia. Sign. 0839/79-84; 0840/29-31; 0889/96; 0904/12.

${ }^{15}$ LORENZO LIMA, Juan Alejandro: "Nuestra Señora del Carmen y el arte genovés de su tiempo en Canarias. Nuevas propuestas de análisis", en Vitis florígera. La Virgen del Carmen de Los Relajos, emblema de fe, arte e historia. Los Realejos. Los Realejos, 2013, pp. 179-180.

16 MARTÍNEZ DE LA PEÑA Y GONZÁLEZ, Domingo: "El retablo de San Vicente Ferrer. Iglesia de San Agustín”, Semana Santa. Icod de los Vinos, 2010, pp. 9-15.

${ }^{17}$ RODRÍGUEZ MORALES, Carlos: "El icodense...", op. cit., p. 27.
} 
Ignoramos los motivos que justifican un retraso tan extraño en el encargo de la escultura de San José, pero cabe la posibilidad de que el precio convenido después de 1786 no fuera del agrado del fraile o que por una u otra razón sus consultas resultasen inviables en Cádiz y Sevilla. Lo cierto es que no volvemos a tener noticias de la efigie hasta 1801, años después de que fray Antonio detentara el cargo de prior (1788-1792). Las lagunas documentales del fondo Zárate Cólogan impiden conocer lo que sucedió entonces, aunque, como reveló Rodríguez Morales, ya en diciembre de 1801 el comisionado José Miguel Joanico Sabater informaba a los Cólogan que en el navío Nuestra Señora del Carmen que capitaneó Simón de Echevarría había embarcado "un cajón tosco con la marca A. P. que dentro contiene una imagen del Señor San José con su Niño y peana, todo de madera, y de cuerpo entero". Pedía a sus remitentes que se responsabilizaran de recogerla en el puerto de Santa Cruz y "darle seguro destino hasta el lugar de Icod, para que [junto a la carta correspondiente de presentación, no localizada o perdida], sea entregada al reverendo padre fray Antonio Perdomo de la Orden de San Agustín, quien es legítimo dueño de dicha imagen"18. Esta misiva prueba que los hermanos Cólogan subcontrataron la hechura con Joanico Sabater y no con sus primos o allegados de confianza en el sur peninsular, por lo que ese intermediario fue responsable del encargo, pago y transporte desde la ciudad de Cádiz. De su actividad mercantil en los puertos de Cádiz y Barcelona hemos reunido algunas noticias de interés, si bien a principios del siglo XIX era partícipe de un pleito que pretendía anular el testamento de su pariente y también famoso comerciante José Pedro Sabater ${ }^{19}$.

La llegada de la imagen a Icod en 1802 debió ser un acontecimiento sonado, sobre todo para el mismo fray Antonio que con anterioridad, en agosto de 1796, había escrito a representantes de los Cólogan con el propósito de no demorar el envío de un hábito bordado para San Agustín que adquirió también en Cádiz ${ }^{20}$. De su aseo y entronización en el retablo ya aludido de San José pudo encargarse el propio religioso, aunque años más tarde, en 1813, su hermana Beatriz custodiaba en el domicilio familiar las alhajas de plata con que la obra era adornaba de forma extraordinaria, esencialmente "la corona del patriarca San José, dorada; [y] otra del Niño, ajada y hecha pedazos" 21.

El envío de esa talla y del resto piezas que corrieron a cuenta de fray Antonio demuestra la idoneidad de encargos formulados a través de la casa Cólogan, porque, de alguna u otra forma, las peticiones isleñas fueron una salida rentable para manufacturas producidas en la Baja Andalucía y describen un panorama

${ }_{18}$ Ibídem, pp. 25-27.

${ }^{19}$ Cfr. Memoria por la masa de acreedores del difunto José Pedro Sabater... Madrid, 1828.

${ }^{20}$ RODRÍGUEZ MORALES, Carlos: "El icodense...”, op. cit., p. 28.

${ }^{21}$ RODRÍGUEZ MORALES, Carlos: Los conventos..., op. cit., t. I, p. 139; t. II, p. 353. 
complejo de contactos e intereses, donde las relaciones personales se entremezclan a veces con las afectivas y familiares. En este sentido, no conviene olvidar que fray Antonio era primo de Bernarda Isabel Pérez Domínguez, fundadora de la capilla de los Dolores anexa al convento franciscano de Icod que tuvo desde 1771 como titulares a la Virgen de los Dolores y al Cristo atado a la Columna, adscritas por Gómez Luis-Ravelo al imaginero sevillano Benito de Hita y Casti1lo (1714-1784) $)^{22}$.

Sin alcanzar la prestancia de esas creaciones, el San José que tratamos es una obra de interés por su cualidad testimonial e histórica (Figura 1). Aunque se vinculó en un primer momento con las formas de dicho escultor y con los obradores hispalenses, proponemos ahora su relación con artífices de la bahía de Cádiz. El intermediario Joanico Sabater debió concretar la hechura con un maestro de su entorno y no de la ciudad distante de Sevilla, hipótesis que, por otra parte, avala el estudio de la pieza. En su acabado, simple y convencional, afloran los rasgos del incipiente clasicismo por medio del aplomo con que fue concebida la representación, su resolución volumétrica, la reducción de la talla a los elementos imprescindibles y la configuración de la peana o base con volúmenes regulares, algo en lo que insiste también la simplicidad del atuendo y de un estudio iconográfico sin mayores novedades o alicientes, que completaba -y hasta cierto punto mejoraría en lo visual- la figuración perdida del Niño Jesús. A ello contribuye igualmente la unidad conferida a las carnaciones, el marmolado original de la peana y el ornato armónico del atuendo, donde se atisba cierta superación de los repertorios de gusto rococó por medio del contraste cromático que habían puesto de moda los paños naturales. En este caso, su vistosidad es mayor gracias a una oposición no tan habitual entre verdes y dorados, estofes sencillos junto a repertorios florales de estuco con poco relieve para la túnica, y motivos semejantes que fueron incisos o dispuestos a punta de pincel sobre el oro visto de un manto bellamente matizado. A ello cabe unir la simulación fiel de los galones sobredorados, adornados, a su vez, con picado de lustre y barnices broncíneos que codifican soluciones o repertorios comunes para lo que ha dado en llamarse policromía neoclásica $^{23}$.

Las cualidades advertidas confirman que la escultura guarda relación con maestros que laboraban a finales del Antiguo Régimen en Cádiz, reinterpretando la imaginería ligur del siglo precedente y, dentro de lo posible, generando una manera o lenguaje propio (Figura 2). Las facciones del santo con cierta dulzura, ojos pequeños y rasgados, nariz prominente, boca entreabierta, barba corta y

${ }^{22}$ GÓMEZ LUIS-RAVELO, Juan: "Las formas artísticas del escultor Benito Hita y Castillo y su profunda huella en esculturas devocionales de Ycod", Semana Santa. Revista del patrimonio histórico-religioso de Ycod, 1997, s/p.

${ }^{23}$ BARTOLOMÉ GARCÍA, Fernando R.: "Las claves de la policromía neoclásica", Akobe: conservación y restauración de bines culturales, 14, 2006, pp. 14-18. 
cabello de poco volumen remiten al estilo de un escultor con fama en la ciudad durante aquella época: el genovés Domenico Giscardi (1725-1805), quien atendió un obrador activo con oficiales de diversa condición para satisfacer la demanda local ${ }^{24}$. Avala tal vínculo la comparativa de su rostro con los rasgos fisonómicos que repitió dicho autor - bien definidos en sus figuraciones de Cristo Resucitado o en las que integran el grupo de San Rafael y Tobías de la iglesia capitalina de San Antonio-y, muy especialmente, la existencia de efigies parecidas de San José en iglesias gaditanas que pueden asociarse de alguna u otra forma con su arte, resultando afines las existentes en el templo hospitalario de San Juan de Dios y la capilla real del Pópulo (Figura 4). En todo caso, como nos previene Lorenzo Alonso de la Sierra, la talla icodense codifica una evolución respecto a los modos de dicho artífice y confirma las fluctuaciones estéticas que vislumbran trabajos asignados a Giscardi en el tránsito de los siglos XVIII y XIX, cuando el estilo de sus últimas creaciones fue permeable a los cambios que introducía el ya popular academicismo o rigorismo de acento neoclásico.

\section{UNA PAREJA DE SANTOS HOSPITALARIOS PARA LA OROTAVA}

En 1804, después de que se bendijera el San José de Icod de los Vinos, arribaban a La Orotava dos esculturas para ornamentar la capilla del ya renovado hospital de la Santísima Trinidad (Figuras 5-6). Su encargo despierta interés por razones muy diversas, aunque, desde un punto de vista cronológico, sendas representaciones de San Juan de Dios y San Rafael Arcángel anteceden a los trabajos que Fernando Estévez afrontó desde 1809 en su obrador de la Villa. Adquieren mayor notoriedad en clave histórica o piadosa, al convertirse en el referente devocional de una rehabilitación que el mayordomo y administrador Miguel Llarena promovió en dicho inmueble desde la década de 1790. Fundado en el siglo XVI y trasladado a su nuevo emplazamiento del Llano de San Sebastián un siglo después, el hospital era entonces un inmueble amplio y saneado, que atendió con problemas las necesidades del vecindario residente en dicha localidad y en otras cercanas que se beneficiaban de los servicios prestados por sus facultativos ${ }^{25}$.

${ }^{24}$ Sobre este maestro véase, entre otros, HORMIGO SÁNCHEZ, Enrique: "Las obras en Cádiz del escultor genovés Domingo Giscardi (1725-1805)", Anales de la Real Academia de Bellas Artes de Cádiz, 4, 1986, pp. 87-95; ARANDA LINARES, Carmen; HORMIGO SÁNCHEZ, Enrique; y SÁNCHEZ PEÑA, José Miguel: Scultura lignea genovese a Cadice nel Settecento (opere e documenti). Génova, 1993, pp. 76-83; SÁNCHEZ PEÑA, José Miguel: Escultura genovesa. Artífices del Setecientos en Cádiz. Cádiz, 2006, pp. 125-146.

${ }^{25}$ ALLOZA MORENO, Manuel Ángel y RODRÍGUEZ MESA, Manuel: Misericordia de la Vera Cruz en el beneficio de Taoro, desde el siglo XVI. Santa Cruz de Tenerife, 1984, pp. 51-96. 
Desde el restablecimiento en la nueva sede del Llano, el hospital contó con una capilla donde toda clase de clérigos oficiaban misas para los enfermos del centro y los vecinos que vivían en sus proximidades. Antiguos inventarios $-\mathrm{y}$ de forma especial el de mayor antigüedad que conocemos, datado en 1738- confirman que las devociones principales del centro fueron siempre la Virgen del Socorro y San Juan de Dios, aunque en el caso del último sus fiestas eran celebradas desde al menos $1692^{26}$. Los problemas que originó la administración de los bienes que pertenecieron a la mayordomía, el complejo cobro de tributos y la amenaza constante de incautación por parte del Estado determinarían que en los primeros años del siglo XIX Llarena vendiese varias propiedades e invirtiera el dinero recaudado en su aseo, el pago de deudas pendientes, avances en la dotación sanitaria y ciertas mejoras que procuró a la infraestructura arquitectónica. Parte del dinero obtenido durante ese periodo, al parecer un total de 200 pesos, se destinó a la sustitución de efigies que existieron en el único retablo que poseía la capilla de los enfermos, no la vecina ermita de San Sebastián como ha llegado a afirmarse en alguna ocasión ${ }^{27}$.

Lo que tuvo lugar entonces fue la compra de un cáliz de plata para reemplazar al sustraído tiempo antes y no una renovación prevista de la antigua Virgen del Socorro, efigie de vestir que el inventario de 1738 describe sin joyas ni coronas de plata pero sí ataviada con un traje de raso verde y un manto azul listado, todo "de mucho uso"28. No figura ya en el registro de 1812, donde, en cambio, sí son citadas las nuevas tallas de Andalucía que tratamos junto a un crucifijo y el cuadro subsistente de la Santísima Trinidad, titular del recinto ${ }^{29}$. De ahí que esos bienes y no otros fueran llevados al convento de San Francisco durante la década de 1840, cuando el hospital acabaría instalándose en sus dependencias de un modo definitivo. Inventarios tardíos de ese templo, convertido ya en iglesia del antiquísimo hospital de la Trinidad, confirman la existencia allí de las representaciones descritas y de enseres que poseyó el inmueble ruinoso del Llano ${ }^{30}$.

Al igual que otros comitentes del siglo XVIII, Llarena confió el encargo de ambas obras a un intermediario activo en Cádiz: el agente mercantil José de Retortillo (1735-1803), personaje que hemos destacado en trabajos previos como promotor artístico y dinamizador del comercio canario en puertos del Caribe y de

${ }^{26}$ Archivo Parroquial Nuestra Señora de la Concepción, La Orotava (APCLO): Libro VI de entierros, f. 146. Cit. ALLOZA MORENO, Manuel Ángel y RODRÍGUEZ MESA, Manuel: Misericordia..., op. cit., p. 311.

27 Aclara esta circunstancia LUQUE HERNÁNDEZ, Antonio: La Orotava, corazón de Tenerife. La Orotava, 1998, pp. 209, 219-220.

${ }^{28}$ Archivo Hospital de la Santísima Trinidad, La Orotava (AHTLO): Caja “papeles varios", sin clasificar.

${ }^{29}$ AHTLO: Caja "papeles varios", sin clasificar.

${ }^{30}$ APCLO: Caja “inventarios". Inventarios de la iglesia de San Francisco, sin clasificar. 
la Península. Atendió peticiones similares desde la década de 1760 y, entre otras gestiones, gracias a su mediación pudieron importarse varias tallas de Hita y Castillo, alhajas de plata, objetos suntuarios, piezas de cuero, una cantidad ingente de pipas de aceite, alfombras, instrumentos musicales y quincallería o todo tipo de bienes que conllevaba el menaje doméstico ${ }^{31}$. La petición del hospital de La Orotava fue uno de los últimos encargos que atendió para el Archipiélago, puesto que su muerte obligaría a que la condesa viuda de Torres, su mujer, ajustara en 1804 el cobro y envío de sendas representaciones hasta Canarias. Todo indica que la contratación con un escultor andaluz fue acuerdo convenido y cerrado en fecha previa, porque, hasta donde sabemos ahora, ni Llarena ni el hospital villero figuran entre quienes debían dinero o géneros a Retortillo al tiempo de su muerte. Así lo ponen de manifiesto varios documentos de 1806, aunque el inventario de los libros y papeles que dejó dicho comerciante recoge anotaciones sobre algunos isleños por ese motivo y los identifica como parientes de quienes le confiaron el envío de esculturas, pilas de mármol y alhajas de plata a lo largo del Setecientos ${ }^{32}$.

El encargo de tales obras desembocó en varias novedades, siendo una de ellas la introducción del culto a San Rafael en la capilla hospitalaria de La Orotava. La existencia de una efigie u otra representación suya no consta en el inventario de $1738^{33} \mathrm{y}$, que sepamos, su vínculo con el centro y con la orden de San Juan de Dios forma parte de los convencionalismos píos del Setecientos, ya que, por citar un ejemplo concreto, desde al menos 1757 la cofradía y la imagen de ese santo existentes en La Laguna respondieron al fin asistencial que tanto nos interesa ahora ${ }^{34}$. De ahí que en ambos casos el arcángel vista el escapulario de los hermanos hospitalarios y se manifieste entregando alimentos de forma caritativa, al tiempo que resguarda las viandas acostumbradas junto al pecho y bajo el hábito descrito. Ese prototipo o estudio representativo no fue ajeno a la estampa devocional del siglo XVIII, por lo que ejemplos ya aducidos al respecto y modelos populares en el medio andaluz condicionaron el ornato, la composición y el estudio iconográfico de la talla que nos ocupa ${ }^{35}$ (Figura 5).

31 LORENZO LIMA, Juan Alejandro: "Constantes del comercio artístico entre Canarias y Andalucía durante el siglo XVIII”, en Andalucía Barroca [actas del congreso homónimo]. Sevilla, 2009, t. I, pp. 339-350.

32 Archivo Histórico Provincial de Cádiz (AHPC): Protocolos notariales de la ciudad de Cádiz. Legajo 2.225, ff. 349v-351v.

33 AHTLO: Caja "papeles varios", sin clasificar.

34 AMADOR MARRERO. Pablo F. y RODRÍGUEZ MORALES, Carlos: "San Rafael", en Roque de Montpellier. Iconografía de los santos protectores de la peste en Canarias [catálogo de la exposición homónima]. Garachico, 2006, pp. 168-169/nº 39.

35 Ello justifica argumentos previos que la creyeron una pieza del Setecientos y propiedad del antiguo convento de San Lorenzo, no del hospital que ocupó su edificio tras la desamortización de Mendizábal. Cfr. TRUJILLO RODRÍGUEZ, Alfonso: San Francisco de La Orotava. La Laguna, 1973, pp. 56-57. 
Lo mismo acontece con la imagen del patrón de los pobres San Juan de Dios, cuyo culto en Canarias no fue extremadamente popular y respondió en muchos casos a iniciativas particulares o celebraciones instituidas en torno a iglesias hospitalarias y conventuales ${ }^{36}$. Partiendo de los convencionalismos en que se desenvuelven habitualmente sus representaciones ${ }^{37}$, la efigie que tratamos de $\mathrm{La}$ Orotava pudo amoldarse a la variante figurativa de santo fundador, puesto que, de acuerdo a lo descrito en inventarios del siglo XIX, portaba en sus manos un estandarte y la corona de espinas como atributos propios ${ }^{38}$ (Figura 6). Además, al ser obra estofada y de talla completa, su acabado y el planteamiento iconográfico difirieron de la imagen vestidera que acabaría reemplazando desde 1804. El registro de bienes tantas veces citado de 1738 alude a su ornato con un crucifijo de plata y un hábito nuevo compuesto por escapulario, capilla, capa y amito, aunque para diario contaba con un atuendo semejante "todo usado" y "un rosario que tiene al cuello con las cuentas grandes negras, colocadas en cordón" "39.

En un estudio anterior defendimos que Retortillo pudo subcontratar esta pareja de imágenes en Sevilla ${ }^{40}$, pero, sin descartar del todo dicha hipótesis, nos decantamos ahora por situar su ejecución en Cádiz. Varias razones avalan esta propuesta, ya que resulta clarificador el paralelismo existente entre la representación del arcángel y otra homónima que Antón María Maragliano esculpió en 1726 para la iglesia hospitalaria de Cádiz por encargo del comerciante Angelo Maria $\mathrm{Necco}^{41}$ (Figura 8). Aunque no se haya explicado de un modo convincente, es probable que tal solución iconográfica, popular en Andalucía desde el siglo anterior, fuese estipulada en Génova a la hora de formalizar el contrato de la vistosa talla de Maragliano. De ahí que algunos investigadores defiendan la posibilidad de que el modelo sea italiano y justifiquen su notoriedad en base a importaciones foráneas ${ }^{42}$. Sin embargo, conociendo el abundante número de estampas y obras escultóricas que lo repiten con fidelidad en nuestro país, preferimos situar el origen de ese prototipo en España y explicar así la afinidad de dicho trabajo con efigies contratadas en el Levante, Madrid y Andalucía a lo largo del siglo XVIII.

${ }^{36}$ HERNÁNDEZ GONZÁLEZ, Manuel Jesús: "San Juan de Dios", en La colección Ossuna: visiones y revisiones. La Laguna, 2014, pp. 131-153.

${ }^{37}$ LARIOS LARIOS, Juan Miguel: San Juan de Dios. La imagen del santo de Granada. Granada, 2006.

38 APCLO: Caja "inventarios". Inventarios de la iglesia de San Francisco, sin clasificar.

39 AHTLO: Caja "papeles varios", sin clasificar.

${ }^{40}$ LORENZO LIMA, Juan Alejandro: "San Juan de Dios” y "San Rafael Arcángel”, en Roque de Montpellier..., op. cit., pp. 164-167/n 37-38.

${ }^{41}$ Comentarios sobre esta importante obra, con bibliografía previa, en la última monografía de SANGUINETI, Daniele: Anton Maria Maragliano. 1664-1739. Génova, 2012, p. $344 / \mathrm{n}^{\circ} \mathrm{I} .100$.

42 VILLANUEVA ROMERO, Eva: “Arcángel San Rafael”, en La imagen reflejada. Andalucía espejo de Europa [catálogo de la exposición homónima]. Cádiz, 2007, pp. 336-337. 
En este sentido, no debe obviarse que las escrituras contractuales firmadas por el mismo Maragliano y otros maestros de Liguria durante la época Moderna recogen a veces pormenores iconográficos con una precisión extrema, hasta el punto de que dejarían poca capacidad de improvisación a los imagineros y a quienes colaboraron de forma puntual en la definición de sus composiciones ${ }^{43}$.

Lo importante ahora es que la efigie solemne de Cádiz y los grabados que divulgaban su representación con mayor o menor acierto se convirtieron en un modelo común entre los artistas de esa ciudad, porque, al margen de la pieza que tratamos, otras responden a la misma dinámica y son un testimonio inexcusable para confirmar el influjo de la imaginería genovesa hasta bien entrado el siglo XIX. Sirva de ejemplo en este sentido el pequeño San Rafael que decora la capilla sacramental del templo de San Juan Bautista en Chiclana de la Frontera, pareja de una figuración afín del arcángel Gabriel y catalogado como obra gaditano-genovesa de mediados del Setecientos ${ }^{44}$.

Las efigies de La Orotava manifiestan cierta calidad y una valía estética o formal que trasciende a la representación previa de San José, por lo que no pueden vincularse tan fácilmente con el arte de Domenico Giscardi ni con el de otros maestros de los que existe producción conocida en el sur peninsular. Como muchas figuraciones esculpidas en Cádiz a finales del Antiguo Régimen, sendas tallas codifican rasgos aplicables a la imaginería genovesa del siglo XVIII y, por consiguiente, manifiestan una elegancia innata en la definición de rostros, gestos y tejidos. Ello no impide, sin embargo, que su acabado muestre rasgos que preconizan el clasicismo posterior. Tal circunstancia queda patente en la simplicidad de los volúmenes y del cromatismo, la mesura que alientan los movimientos o la sencillez de sus peanas, decoradas con simulacros marmóreos al uso. En esa novedad se inscribe también el acierto de las carnaciones - de mayor riqueza en la cabeza del arcángel, con bellas matizaciones en los sonrosados de las mejillas y de los brazos- y la simpleza de unos estofes que reproducen motivos florales sin obviar la simulación de acabados textiles o contrastes armónicos en base al oro (Figura 7).

${ }^{43}$ Cfr. SANGUNIETI, Daniele: Anton Maria Maragliano..., op. cit., pp. 79-88; 435443; y SANGUNETI, Daniele: Scultura genovese in legno policromo dal secondo Cinquecento al Setecento. Turín, 2013, pp. 74-81.

${ }^{44}$ ALONSO DE LA SIERRA FERNÁNDEZ, Lorenzo y ALONSO DE LA SIERRA FERNÁNDEZ, Juan: Estelas de piedad. Patrimonio artístico religioso de Chiclana de la Frontera [catálogo de la exposición homónima]. Chiclana de la Frontera, 2003, pp. $84-85 / n^{\circ} 37-38$. 


\section{LA INMACULADA DEL CONVENTO DE MONJAS CONCEPCIONISTAS DE GARACHICO}

Obviando las obras ya descritas de Icod y La Orotava, la escultura de mayor interés que arribó desde Andalucía a principios del siglo XIX recibe culto en el monasterio de las monjas concepcionistas de Garachico (Figura 9). Se trata de la Inmaculada que preside el retablo mayor de su templo y no fue bendecida hasta febrero de 1819, aunque, como sucede siempre, los contactos para ajustar el encargo comenzaron años antes. Los pormenores de la contratación, las recomendaciones expresadas al autor en diversos momentos y el envío posterior desde Cádiz fueron relatados de modo minucioso por fray José González Oliva, quien moraba en el convento próximo de frailes agustinos y mantuvo entonces una relación estrecha con sor Isabel de San Manuel de Castillo, religiosa a quien se debe en última instancia su adquisición. Ello explica que escribiera una corta memoria en el libro de mandatos del monasterio ${ }^{45}$ y que su elocuente narración, tan precisa a veces, sirviese a investigadores previos para dar noticia de los orígenes de la imagen y de otros pormenores históricos con detalle ${ }^{46}$. Sin embargo, leyendo detenidamente esa relación de hechos y contextualizándola con otros documentos de la época, llegamos al convencimiento de que la efigie reviste un interés mayor del que puede advertirse a simple vista por su acabado o cualidad formal.

De acuerdo a la narración de González Oliva, los trámites para concretar su hechura empezaron en 1816. Sor Isabel de San Manuel del Castillo era ya una religiosa de probadas virtudes, puesto que profesó en 1786 con dote de 400 pesos y sería reelegida como abadesa o priora nueve veces consecutivas desde $1804^{47}$. Hija de Manuel Alonso del Castillo y de María Bautista, nació en La Rambla en marzo de $1759^{48} \mathrm{y}$, como otros parientes de su mismo estatus, desarrolló una vida acorde a los convencionalismos píos del momento. Fue hermana del militar y rico indiano Manuel Vicente del Castillo, a quien se debe, entre otras actuaciones, la entronización de una efigie vestidera de la Inmaculada en la capilla que construyó

45 AHPT: Conventos. Sign. 266, ff. 94r-94v.

46 Olvidada con frecuencia o citada sin más en ensayos genéricos, de la obra se ocuparon con anterioridad INCHAURBE, Diego: Historia de los conventos de Santa Clara de La Laguna y de San Pedro Apóstol y San Cristóbal de Garachico. Sevilla, 1943, p. 301; VELÁZQUEZ MÉNDEZ, José: "Una Inmaculada sevillana para el V centenario de la Orden Concepcionista", La Prensa del Domingo [suplemento cultural del periódico El Día], Santa Cruz de Tenerife, 21/5/1989, p. 10; y ACOSTA GARCÍA, Carlos: Apuntes generales sobre la historia de Garachico. Santa Cruz de Tenerife, 1994, p. 266.

${ }^{47}$ AHPT: Conventos. Sign. 265, s/f. Cit. INCHAURBE, Diego: Historia..., op. cit., p. 352 .

48 Archivo Histórico Diocesano de La Laguna (AHDLL): Fondo parroquial San Juan Bautista, San Juan de La Rambla. Libro VI de bautismos, f. 158v. 
anexa a la parroquia de San Juan durante la década de $1790^{49}$. Dicho comitente no se olvidaría de ella en cuantos testamentos y codicilos firmó al final de su vida, de modo que, al partir la herencia en 1817, Isabel la monja sería beneficiada con algunas cantidades de dinero ${ }^{50}$; y años antes, sus generosas retribuciones le ayudaron a vivir sin estrecheces en el claustro de un convento en franca decadencia, porque, aunque fue fundado por Cristóbal de Ponte y Hoyo en 1643, un incendio lo dejó en la ruina desde 1709. Reedificado por el obispo Juan Francisco Guillén durante la década de 1740, la protección del prelado permitió que sus moradoras permanecieran desde entonces bajo la tutela episcopal. Luego, la crisis de valores religiosos que trajo consigo el siglo XIX y la residencia en él de varias monjas del monasterio icodense de San Bernardo acabaron con lo que Isabel llamaba a veces "rectitud en la clausura", de modo que dichos contratiempos y graves problemas económicos lastraron la existencia del convento durante la contemporaneidad.

Documentos generados por la propia abadesa hasta el mismo tiempo de su muerte en 1831 previenen acerca de las actividades emprendidas en el monasterio, aunque años antes pedía al obispo Folgueras que la librara del cargo de superiora o presidenta para "llevar una vida más cómoda en el claustro" 51 . No obstante, el nombramiento como tal en 1807, las poesías que le dedicaron sus allegados y otras circunstancias que el párroco Francisco Martínez de Fuentes describe en Vida Literaria ${ }^{52}$ nos ayudan a comprender la satisfacción generada en el pueblo con su labor. Desde luego, ese ánimo creciente alentó años después el encargo de "una imagen grande de la Inmaculada", en cuyo pago iba a invertir la religiosa parte del dinero que le correspondió por herencia de su hermano Manuel Vicente y lo recaudado entre varias monjas de la comunidad, los clérigos y el vecindario de la zona.

Fray José González Oliva relata que el encargado de su contratación y pago fue el caballero de la Orden de Carlos III José Verger, quien se había significado en Sevilla como opositor a la ocupación francesa después de 1808 y, de forma pragmática junto a su mujer María de las Mercedes Rodríguez de Rivera, como mayordomo y miembro destacado de la hermandad de los Negritos ${ }^{53}$. Era, en realidad, un comerciante al pormayor y hombre de férreas ideas absolutistas que

${ }^{49}$ Cfr. RODRÍGUEZ MESA, Manuel y ALlOZA MORENO, Manuel Ángel: "Arte americano en San Juan de La Rambla y otras noticias para su historia”, en Serta Gratvlatoria in honorem Juan Régulo. La Laguna, 1990, t. IV, pp. 37-71.

${ }_{50}$ AHPT: Protocolos Notariales. Legajo 3.296, ff. 740r, 741v, 743r; y legajo 3.520, ff. $68 \mathrm{v}, 69 \mathrm{v}$.

51 AHDLL: Fondo histórico diocesano. Legajo 1.511, documento 19.

${ }^{52}$ Cfr. Archivo de la Real Sociedad Económica de Amigos del País de Tenerife (ARSEAPT): Fondo Rodríguez Moure. RM 257 (22/32), t. III-v.7, ff. 43v-49r.

${ }^{53}$ MORENO NAVARRO, Isidoro: La antigua hermandad de los negritos de Sevilla. Etnicidad, poder y sociedad en 600 años de historia. Sevilla, 1997, pp. 257, 263-265; 
ocupó los cargos de cónsul (1798-1799) y prior (1808-1809) del Consulado Marítimo y Terrestre de Sevilla durante una época verdaderamente compleja para todo $^{54}$. Se trató de un intermediario solvente y de confianza, por lo que, a través del habitual contacto epistolar, Verger tuvo conocimiento de cuantos reclamos y peticiones hicieron las monjas antes de ajustar su efigie. Se le indicaron medidas aproximadas de una vara y media de alto "fuera del mundo y la peana", además del requisito obligado de que el autor "la hiciese copiar por la escultura de más gusto que hubiese en la ciudad de Sevilla” o, como trataremos luego, sin eludir el influjo murillesco que impregnaba a la creación artística durante aquel periodo.

José Verger cumpliría fielmente con su cometido y, después de más de dos años de espera, entregó la imagen debidamente embalada y encajonada al capitán Orta, quien la condujo en navío propio desde Cádiz hasta el puerto de Santa Cruz de Tenerife. A la isla arribó en febrero de 1819 y fue recogida de inmediato por Rafael Contreras, corresponsal en la isla del citado Verger. Contreras es un personaje conocido en el Archipiélago por su actividad comercial en torno a los puertos principales de Tenerife y Gran Canaria, pero, al igual que sucede con Verger, ignoramos si medió en el encargo de otras manufacturas artísticas que se contrataron entonces desde Canarias ${ }^{55}$. El traslado no fue fácil, habida cuenta de que en esos momentos "los mares estaban infectados de corsarios, insurgentes de Buenos Aires [alusión clara a los problemas que originó la independencia de ese país, en fecha previa a la aprobación de su texto constitucional de 1819], y bajo el nombre y capa de ellos de piratas de todas las naciones, especialmente de ingleses americanos". Ante ese panorama, la llegada sin perjuicio de una obra que representaba "a la mejor Judit" se tornó en algo milagroso. Nada más recoger la Virgen, Cárdenas envió carta a fray José Lorenzo Estévez de la Guardia, agustino residente en La Orotava que se había revelado ya como un excelente patrocinador de las artes en su convento ${ }^{56}$ y estaba al tanto de la recepción. A su vez, Estévez escribió a

SEGURA MÁRQUEZ, Francisco Javier: "Hermandades y franceses (1810-1812): patrimonio, fe y política", en XIV simposio sobre hermandades de Sevilla y su provincia. Sevilla, 2013, p. 156.

${ }^{54}$ HEREDIA HERRERA, Antonia: "El Consulado nuevo de Sevilla y América", Andalucía y América en el siglo XIX [actas de las V jornadas Andalucía y América]. Sevi1la, 1984, pp. 299-300.

${ }_{55}$ De sus actividades como intermediarios o promotores se han publicado ya varias noticias, al constatar que, por ejemplo, Verger pagó en 1815 algunos textiles al bordador Juan Bautista Carrasco y Alaraz para la hermandad sacramental de la colegiata sevillana del Salvador. Cfr. RODA PEÑA, José: "La colección de bordados de la archicofradía sacramental del Salvador de Sevilla", en XV Simposio sobre Hermandades de Sevilla y su provincia. Sevilla, 2013, p. 244.

${ }^{56}$ Entre otras medidas, años antes concertó con el escultor Fernando Estévez la ejecución de una efigie de Santo Tomás de Villanueva, colocada en 1816. LORENZO LIMA, Juan Alejandro: "Comentarios en torno a un retablo. Noticias de Fernando Estévez y la 
González Oliva como provincial de la Orden que residía en Garachico y capellán de las monjas durante algo más de dieciocho años, por lo que junto a sor Isabel figura citado como "móvil del encargo".

De forma unánime y para no pretender nuevos milagros ni tentar a Dios, todos decidieron conducir la efigie por tierra y no por mar como estaba previsto. Evitaron así a los corsarios ya referidos, quienes en días previos habían apresado con escándalo varias embarcaciones del comercio interinsular. Sin tiempo que perder, el arriero José Álvarez, casado en el barrio de Las Cruces con Catalina Martínez, se personaba en Santa Cruz el 18 de febrero, cargó con sumo cuidado el cajón y no llegaría a Garachico con él hasta dos días después. Su recepción el 20 de febrero de 1819 fue todo un acontecimiento, puesto que las religiosas esperaban con ansia "tan misteriosa nave venida de lejos". Algunas se erigieron como atalayas en el mirador o ajimez conventual, de modo que al divisar la bestia de Álvarez a la altura de El Guincho anunciaron su venida con "repiques y voladores que pusieron al pueblo en movimiento". De inmediato, la comunidad de frailes dominicos abandonó su casa y anduvo acompañando "el cajón hasta la puerta reglar [del monasterio de concepcionistas], donde le esperaba la de San Agustín".

La caja que servía "de concha a joya tan peregrina" fue abierta allí mismo por el carpintero y guarda del castillo de San Miguel Francisco Rodríguez, de modo que "al descubrir la efigie y verla tan linda y majestuosa, toda la comunidad en medio de lágrimas de gozo se arrodilló alrededor del cajón y con devoción afectuosa entonó la antífona conceptio tua dei genitrix virgo". A ello le siguió una primera oración de González Oliva, aunque al coincidir ese hecho con la procesión de las bulas el concurso de fieles fue mayor en torno al monasterio. El cortejo que presidía el vicario y párroco Francisco Martínez de Fuentes en medio de repiques, pífanos y tambores entró en el aula reglar y contempló de modo detenido la imagen, colocada ya en "un decente altar prevenido a este fin". El mismo Martínez -que había predicado en las fiestas conventuales de la Inmaculada desde 1801 y mantuvo una estrecha relación con las monjas, especialmente con sor Isabel ${ }^{57}$ la bendijo entonces en medio del estruendo de las campanas y los vivas del pueblo. Horas después, la Virgen fue devuelta a su caja para evitar daños mayores y permaneció en ella hasta que se le proporcionó un "nicho donde guardarla con decencia". Al quedar "encendidas de devoción", esa noche y en los días sucesivos las monjas bajaron a la sala donde se resguardaba la imagen para rezar junto a ella el rosario y cantar las antífonas correspondientes.

Al margen del boato que se deprende de una crónica tan piadosa, no dejan de ser interesantes algunos comentarios que González Oliva escribió sobre la efigie después de participar en su bendición. De ahí que estimara el coste total en 255 pesos

actividad de su taller en La Orotava (1809-1821)", Revista de Historia Canaria, 191, 2009, pp. 112-113.

57 ARSEAPT: Fondo Rodríguez Moure. RM 257 (22/32), t. II-v.4, f. 108r. 
y ponderase la satisfacción que todo ello había originado en sor Manuel del Castillo, quien, según apostilla, "desde el primer año de los quince que tiene de prelada había estado inspirando porque el Señor le diera medios para dejarles una buena imagen de la madre de Dios". No cabe duda de que la pieza colmó las expectativas de la superiora y de una comunidad de monjas con graves problemas económicos, aunque, como era costumbre desde el siglo anterior, cada mes de diciembre invertían parte de sus fondos en organizar la "fiesta anual de la Concepción" con tales alicientes llamara la atención de unos fieles cada vez mejor instruidos en lo artístico y lo devocional, hasta el punto de que meses después, en mayo de 1821, formó parte de una rogativa celebrada en la parroquia de Santa Ana para festejar la elección de Garachico como capital del partido o distrito de Daute ${ }^{59}$. A pesar de ese hecho, ignoramos lo que sucedió entonces con la "nueva Inmaculada" y donde fue colocada para recibir un culto regular, ya que, entre otros documentos, el inventario conventual de 1836 no alude a ella por un posible despiste del redactor. Deducimos, no obstante, que su colocación en la hornacina central del retablo mayor del templo fue inmediata, habida cuenta de que sería contratada con ese fin por la abadesa y sus religiosas; y, a pesar de que en ocasiones se haya expresado lo contrario, no somos partidarios de identificar esta efigie "nueva" con otra del mismo título que el registro ya citado sitúa en el altar de la enfermería, refiriéndola expresamente como "Nuestra Señora de Concepción, de bulto, antigua". Por su tamaño tampoco debe tratarse de la "imagen de Concepción" que remataba el facistol existente en el coro alto, aunque, en cambio, parece probable que sí fuera un adorno suyo la media luna de plata que los comisionados del Crédito Público describen con peso de una libra y seis onzas de plata ${ }^{60}$.

Olvidando los convencionalismos píos ya expuestos, la imagen también llamó la atención por su acabado o cualidades artísticas. En la memoria de 1819 el mismo fray José González Oliva no pudo obviar la mención de un pueblo que "admiraba y celebraba esta hermosa escultura". Precisamente, al tiempo de su entronización provisional para ser bendecida, llegaron al monasterio "diversos sujetos que habían comenzado a admirar en ella los primores y la delicadeza del arte". La cita es del todo oportuna, puesto que en un contexto peculiar como el surgido durante las primeras décadas del siglo XIX los valores devocionales eran tan importantes como el primor o buen acabado que se aducía a la hora de esculpir una figuración de tanto porte e interés. Al margen de los cambios de fondo y forma suscitados en torno al arte durante esa época, la imaginería siguió mostrando una preocupación notable por el aspecto formal de las creaciones, hasta el punto de que tal disyuntiva no pudo evitar el vínculo de sus intérpretes con la

\footnotetext{
58 AHDLL: Fondo histórico diocesano. Legajo 1.355, documento 5.

${ }^{59}$ INCHAURBE, Diego: Historia..., op. cit., p. 201.

${ }^{60}$ AHPT: Conventos. Sign. 270, s/f.
} 
teoría, los modelos y las prácticas que el academicismo popularizó desde la centuria anterior ${ }^{61}$.

En ese sentido, la Inmaculada de Garachico es una efigie meritoria y digna de consideración por sus valores compositivos y estéticos. Un análisis detenido de la misma nos lleva al convencimiento de que es obra del imaginero Juan de Astorga (1777-1849), el más notable de cuantos trabajaron en Sevilla a principios del Ochocientos. Su trayectoria vital y profesional es ya bien conocida, gracias a últimos trabajos que revelan pormenores biográficos y profesionales ${ }^{62}$, su dedicación reiterada al retablo ${ }^{63}$ y una actividad constante como restaurador ${ }^{64}$. En el caso de la pieza tinerfeña, el estudio de sus rasgos estéticos -y particularmente de la cabeza y las manos, únicos dispositivos de talla que eludieron recomendaciones formuladas a la hora de cerrar el encargo- revela afinidad con esculturas documentadas o atribuidas a Astorga como la Virgen del Mayor Dolor de Ceuta, la Dolorosa de Gines, o el San Juanito del monasterio de Santa Paula, la Virgen de la Angustia de la cofradía universitaria y la Soledad de San Ildefonso, las últimas en Sevilla. Sin embargo, como nos indica Roda Peña, guarda una semejanza mayor con la Virgen de la Presentación que recibe culto en el templo de la Magdalena (c. 1820) y con la Dolorosa de los padres capuchinos (c. 1812-1815), ambas en Sevilla, sobre todo en la configuración de una cabeza que posee como rasgos distintivos cierta inclinación hacia un lateral, una rotundidad mayor en los volúmenes, cuello amplio, tendencia al óvalo en la visión frontal del rostro y perfil cuidado por su extrema finura, así como la concreción de una fisionomía reconocible sin dificultad por medio de cejas con líneas suaves, ojos grandes y de gran viveza, párpados caídos, nariz recta, boca pequeña y mentón resaltado, siempre con hoyuelo en la parte central (Figura 10). Aflora en ella lo que Ruiz Alcañiz llamó

${ }^{61}$ HERRERA GARCÍA, Francisco Javier: "Escultura sevillana de la segunda mitad del siglo XVIII: prejuicios, ideas teóricas y algunas atribuciones", Archivo Hispalense, 294296, 2014, pp. 269-293.

${ }^{62}$ RODA PEÑA, José: "Nuevos testimonios biográficos y artísticos sobre el escultor Juan de Astorga", Laboratorio de Arte, 10, 1997, pp. 269-288; AMORES MARTÍNEZ, Francisco: "La obra del escultor Juan de Astorga para la ermita de Cuatrovitas en Bollullos de la Mitación", Laboratorio de Arte, 20, 2007, pp. 281-293; ROS GONZÁLEZ, Francisco S.: "Algunas noticias sobre el tallista José Mayorga y el escultor Juan de Astorga", Laboratorio de Arte, 20, 2007, pp. 295-308; RODA PEÑA, José: "Juan de Astorga: novedades biográficas y aportaciones a su catálogo escultórico", en Nuevas perspectivas críticas sobre historia de la escultura sevillana. Sevilla, 2007, pp. 143-163; AGUILAR DÍAZ, Jesús: "Dos esculturas de Juan de Astorga para el convento de San Agustín de Sevilla", Revista agustiniana, 157, 2011, pp. 7-16.

${ }^{63}$ ROS GONZÁLEZ, Francisco S.: "Los retablos de Juan de Astorga", Laboratorio de Arte, 17, 2004, pp. 281-310.

${ }^{64}$ RODA PEÑA, José: "Juan de Astorga, restaurador", Laboratorio de Arte, 23, 2011, pp. 351-374. 
expresión calmada y sosegada, advirtiendo, además, que tal particularidad confería a sus creaciones la encantadora dulzura que manifiesta nuestra Inmaculada ${ }^{65}$; y en lo relativo a las manos, el fino tallado y su definición volumétrica se prestan a comparativa con las que poseen muchas efigies vestideras del autor, hasta el punto de que son deudoras del mismo patrón con unos dedos largos y estilizados que se repiten constantemente, casi sin diferencias perceptibles (Figura 10).

Un arte tan sugestivo como el de Juan de Astorga y la popularidad ganada con él en la ciudad determinarían que Verger eligiera a dicho maestro para afrontar un encargo llegado desde tan lejos, porque, precisamente, durante la década de 1810 la fama de Astorga era notable y generalizada. Durante el periodo que media entre 1815 y 1820 se sucedieron acontecimientos notables para quien fue un hombre piadoso desde temprana fecha y firmó ya en 1801 como "célebre escultor [...], natural de Archidona, discípulo del excelentísimo escultor don Cristóbal Ramos". En 1810 ocupó una plaza de profesor de escultura en la Escuela local de las Tres Nobles Artes y, hasta donde sabemos ahora, no eludiría entonces los convencionalismos del gusto neoclásico ni la directriz estética que impuso el ya anciano Blas Molner (1737-1812) ${ }^{66}$. El reconocimiento vino dado con su vinculación a la Real Sociedad Económica Sevillana de Amigos del País desde 1818, a raíz de la concesión de una medalla de plata por la aplicación mostrada en sus creaciones más recientes y el ingreso en dicha corporación años después ${ }^{67}$. Fue también un tiempo de dedicación a aparatos efímeros ${ }^{68} \mathrm{y}$ de gran actividad para el taller que mantuvo en el domicilio familiar de la calle Amor de Dios, porque, entre otras, a ese periodo corresponden piezas señeras de su catálogo como el Crucificado de la Escuela de Cristo (1818) o la Virgen de la Esperanza del exconvento de la Trinidad (1819-1820) ${ }^{69}$.

Sea como fuere, el encargo de la Inmaculada que nos ocupa en 1816 debió ser una petición atípica por su gran tamaño y el dispositivo móvil que tuvo en la peana, mecanismo que permitía a la efigie oscilar durante los trayectos procesionales. González Oliva relataba en 1819 que las monjas y sus intermediarios pidieron al autor que "la hiciese copiar por la escultura de más gusto que hubiese en la ciudad”. Tal requisito se codificó en una simplificación respecto a los modelos difundidos por imagineros previos como el ya citado Blas Molner, Cristóbal Ramos o Benito de Hita y Castillo, pero, muy especialmente, en un débito claro hacia las

${ }^{65}$ RUIZ ALCAÑIZ, José Ignacio: El escultor Juan de Astorga [Arte Hispalense, 44]. Sevilla, 1986, pp. 44-45.

${ }^{66}$ Ibídem, p. 14.

${ }^{67}$ RODA PEÑA, José: “Juan de Astorga...”, op. cit., pp. 144-145.

${ }^{68}$ Así lo demuestran el catafalco que se erigió en la catedral para los funerales de la reina María Isabel de Braganza (1819) o el arco de la Calle del Ángel para recibir a Fernando VII posteriormente (1823).

${ }^{69}$ RUIZ ALCAÑIZ, José Ignacio: El escultor..., op. cit., pp. 31-60, 129-133. 
Inmaculadas recreadas por Bartolomé Esteban Murillo (1617-1682) y otros pintores de su tiempo, cuya notoriedad y aprecio estético habían revalorizado desde 1808 las incursiones francesas en la ciudad ${ }^{70}$. Documentos posteriores refieren que la Virgen de Garachico fue "inspirada en los cuadros del célebre Murillo", por lo que tal particularidad nos pone en la pista de modelos que superaban la copia reiterada de yesos y obras clásicas que tanto reivindicó el academicismo latente. En cualquier caso, al margen del mayor o menor vínculo respecto a las creaciones pictóricas, este apunte tardío incide en el valor que Francisco de Bruna y sus contemporáneos concedieron a la formación artística de maestros como Astorga en el seno de la Escuela de las Tres Nobles Artes ${ }^{71}$.

Sin eludir otros puntos de contacto con la imaginería tardobarroca, la Inmaculada de Garachico reinventa creaciones dieciochescas en aras de una sencillez y armonía que es consustancial al gusto moderno o neoclásico que alentó Juan de Astorga (Figura 9). Con cuidada volumetría y estudio gestual, en su composición la imagen reproduce también indicaciones expresadas desde Tenerife por dar cabida en su parte inferior al "mundo" junto a una peana de configuración piramidal, no sin reproducir la iconografía que es habitual para esta figuración en concreto. Ello explica que la Virgen se represente en pie y con las manos recogidas a la altura del pecho, vista el atuendo distintivo y muestre en el orbe la serpiente alusiva al pecado, obviando, eso sí, la media luna y las estrellas que el relato apocalíptico de San Juan describe con precisión. Su correcto tallado participa de cualidades inherentes a la simplificación de formas aludida, algo que remarca la disposición del atavío con aplomo y una elegancia infrecuente para la época. Así lo confirma la combinación armónica de una túnica blanca con escote generoso y puños interiores del mismo color, cinta rosa para ajustar el recogido de la cintura y manto azul sobrepuesto que deja los cabellos al descubierto, cuyos largos pliegues realzan la silueta mariana y le confieren una volumetría de mayor estilización y finura ocultando los pies.

Igual de importante es el tratamiento polícromo, con carnaciones suaves en las manos y en un rostro de tez pálida que muestra el sonrosado común de las mejillas y el mentón. Los estofados de las vestiduras revelan interés y en ellos quedan patentes los rigores del estilo neoclásico. Si la peana luce un marmolado al uso, la vestimenta muestra estofes que simulan de modo fiel los tejidos lisos y brillantes que tanto reivindicó el gusto moderno o la estética ya referida de los paños naturales (Figura 11). De ahí que los rayados sobre el temple manifiesten diverso

${ }^{70}$ Cfr. HEMPEL LIPSCHUT, Ilse: La pintura española y los románticos franceses. Madrid, 1988; GARCÍA FELGUERA, María de los Santos: La fortuna de Murillo (16821900). Sevilla, 1989.

${ }^{71}$ Sobre este particular véase la última interpretación contextual de CABEZAS GARCÍA, Álvaro: Gusto orientado y fiesta púbica en Sevilla. Análisis de documentos para la comprensión de la historia artística del siglo XVIII. Sevilla, 2012. 
grosor y efecto en la recreación de líneas paralelas o puntos que simulan los brillos de la bola terráquea, del manto y de la túnica interior. A ello se suman estucos relevados que adornan los bordes del atuendo, describiendo en la pieza exterior una suerte de losange regular con la combinación de galones a modo de pasamanería fina y formas vegetales de gran estilización, siempre en sintonía con repertorios de la época y motivos que imitan los encajes de aliento rococó (Figura 11). Tal ornamentación es digna de una pieza a tener en cuenta por su vistosidad y buen acabado, porque, al fin y al cabo, codifica los rasgos de la mejor imaginería sevillana de su tiempo.

Fecha de recepción: 14 de septiembre de 2015.

Fecha de aceptación: 20 de noviembre de 2015. 


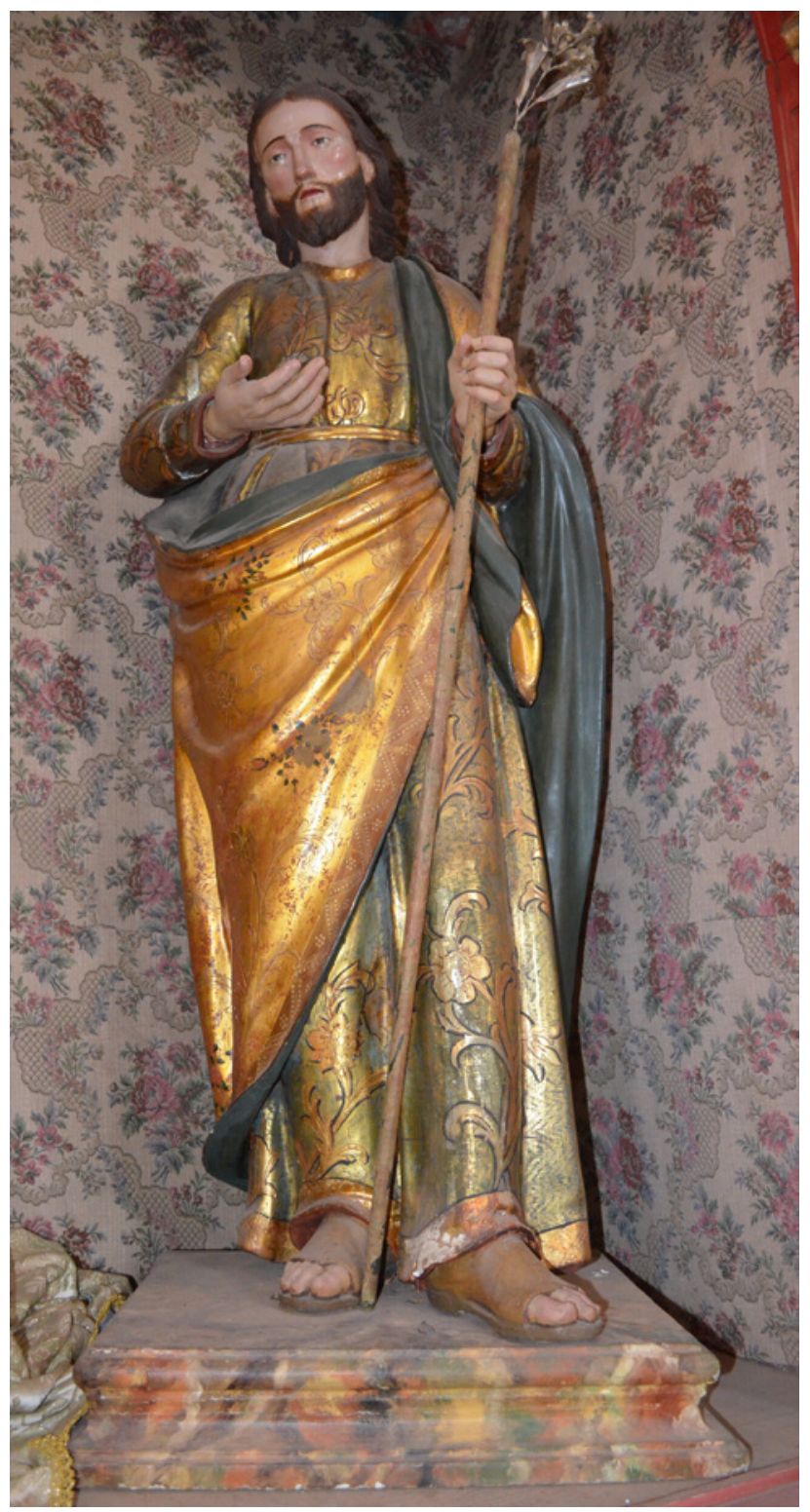

Figura 1. Atribuido a Domenico Giscardi: San José (1801). Iglesia de San Agustín, Icod de los Vinos. Foto: Juan Alejandro Lorenzo. 
Figura 2. Atribuido a Domenico Giscardi: San José (1801) [detalle]. Iglesia de San Agustín, Icod de los Vinos. Foto: Juan Alejandro Lorenzo.

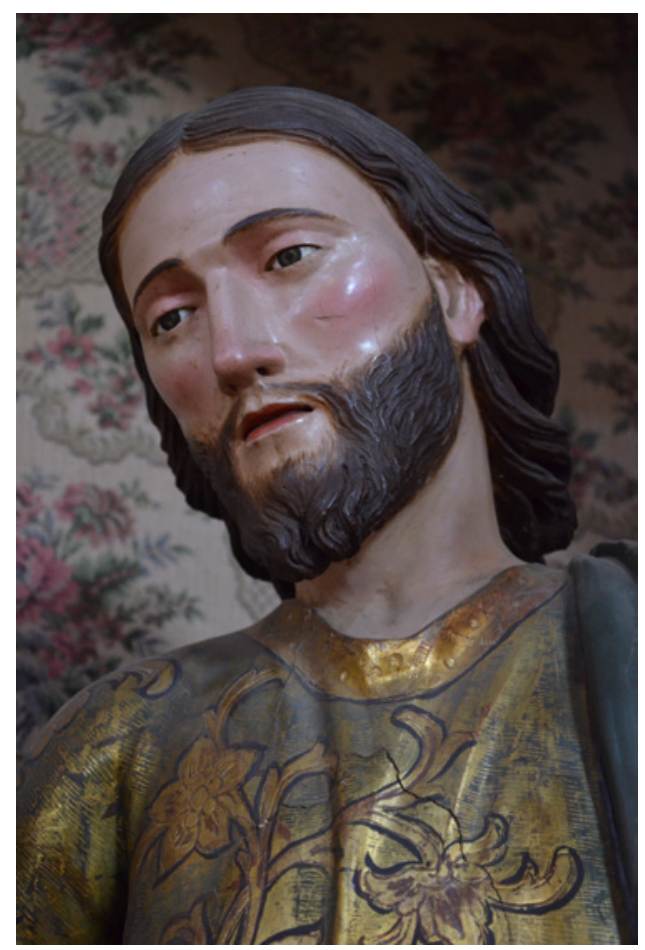

Figura 3. Anónimo genovés: Pila benditera (c. 1785). Iglesia de San Agustín, Icod de los Vinos. Anónimo genovés: Pila benditera (c. 1796). Parroquia de San Marcos, Icod de los Vinos Foto: Juan Alejandro Lorenzo

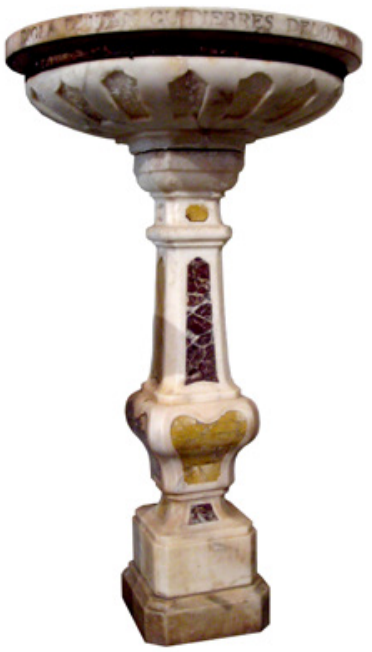




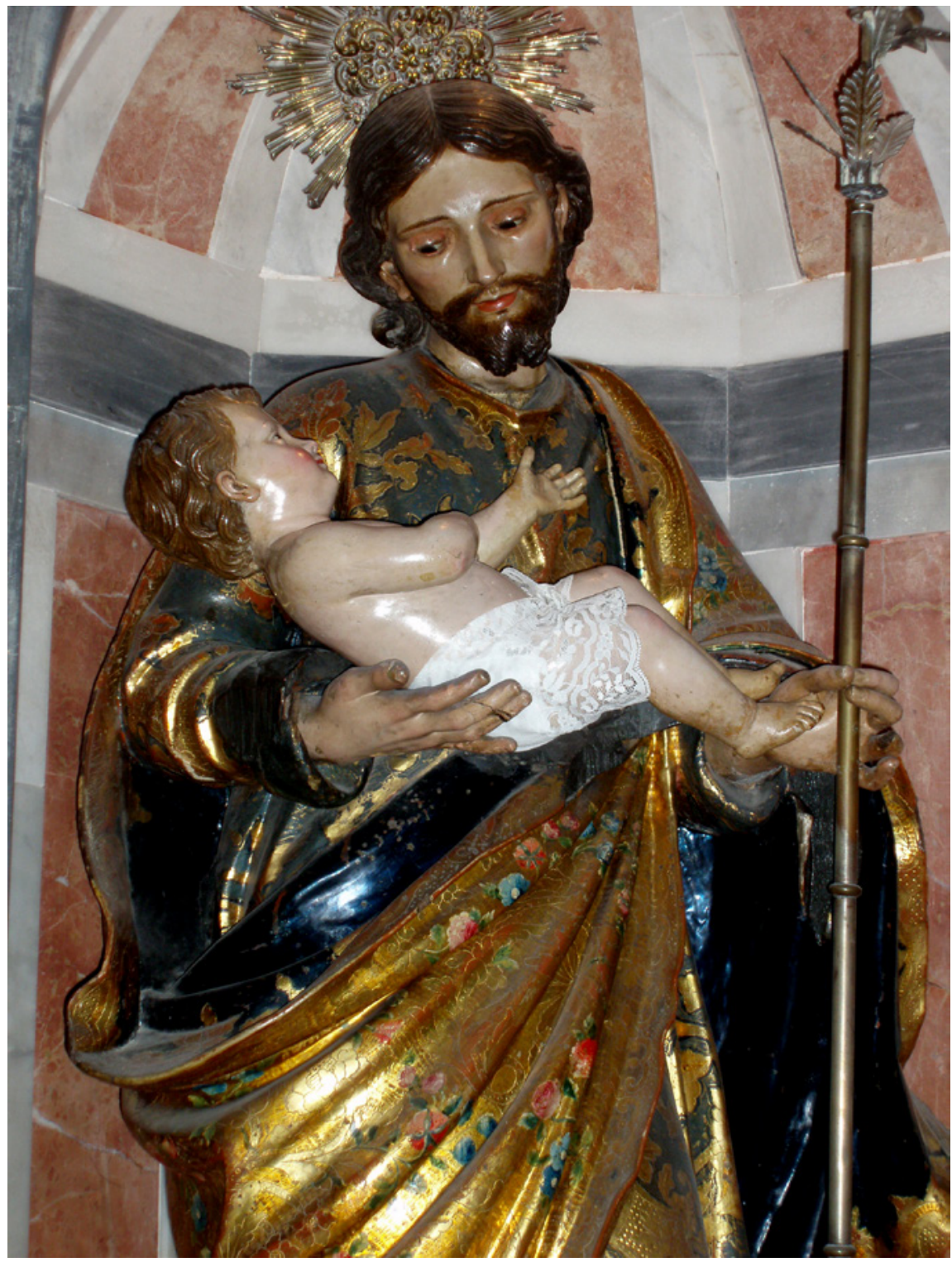

Figura 4. Anónimo gaditano-genovés: San José (c. 1790). Iglesia de San Juan de Dios, Cádiz. Foto: Juan Alejandro Lorenzo. 


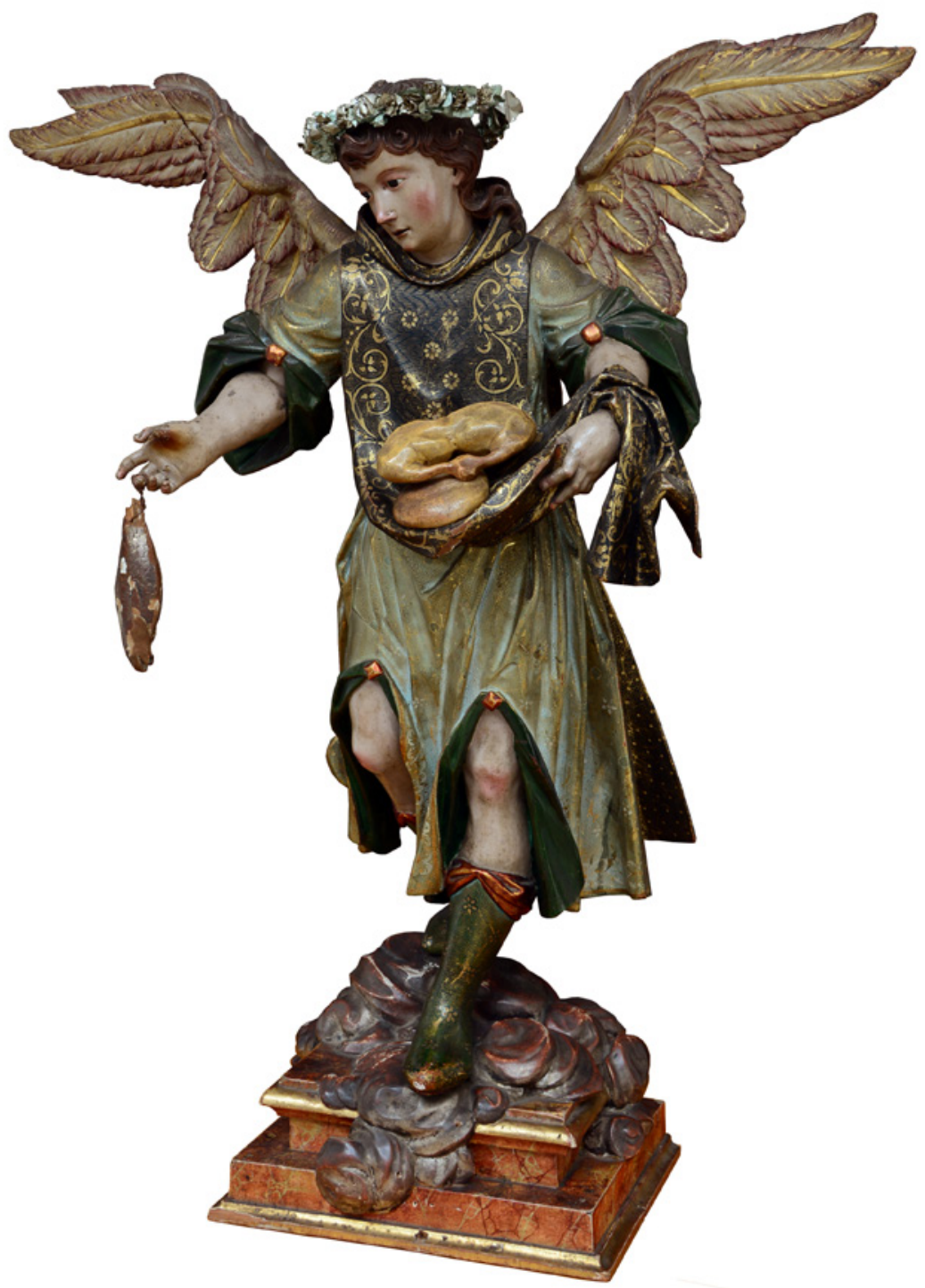

Figura 5. Anónimo gaditano: San Rafael Arcángel (1804). Iglesia de San Francisco, La Orotava. Foto: Josué Hernández. 


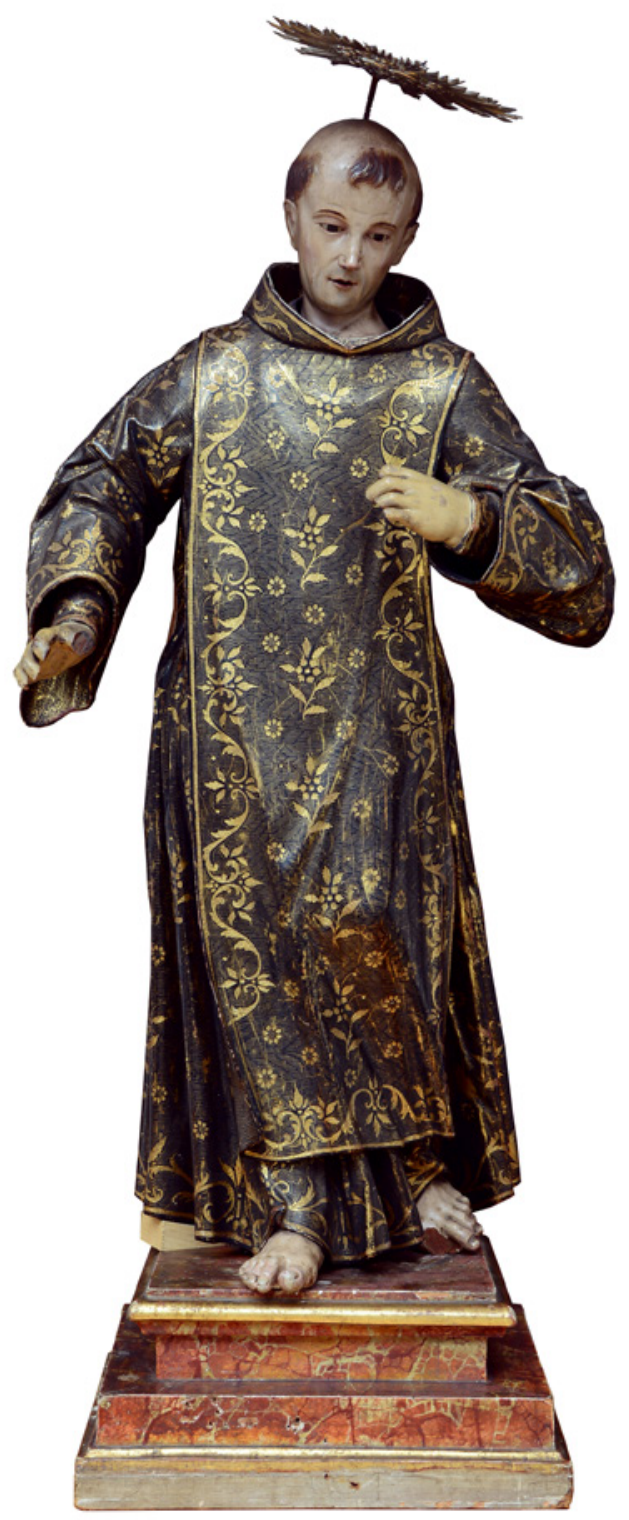

Figura 6. Anónimo gaditano: San Juan de Dios (1804). Iglesia de San Francisco, La Orotava. Foto: Josué Hernández. 


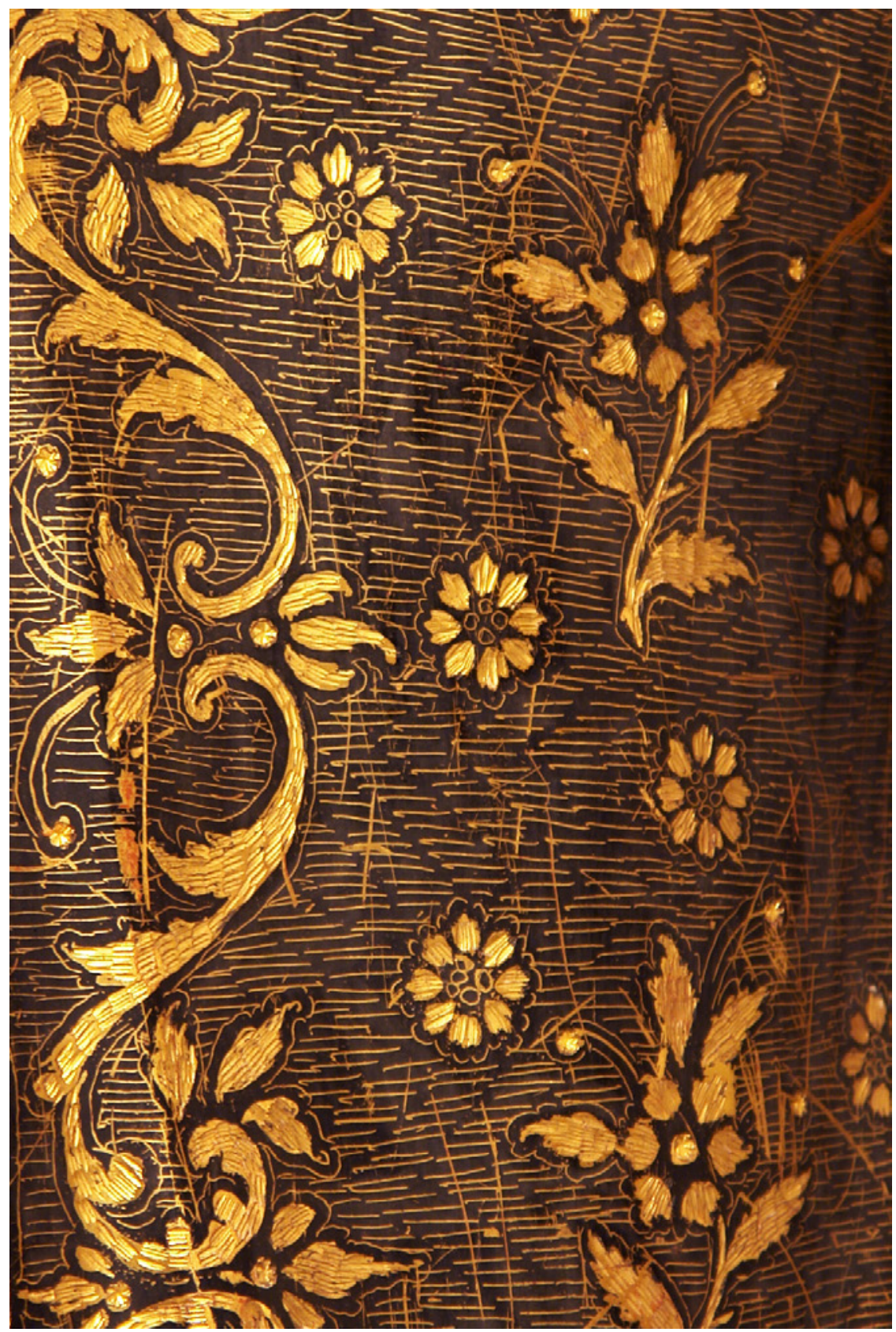

Figura 7. Anónimo gaditano: San Juan de Dios (1804) [detalle]. Iglesia de San Francisco, La Orotava. Foto: Josué Hernández. 


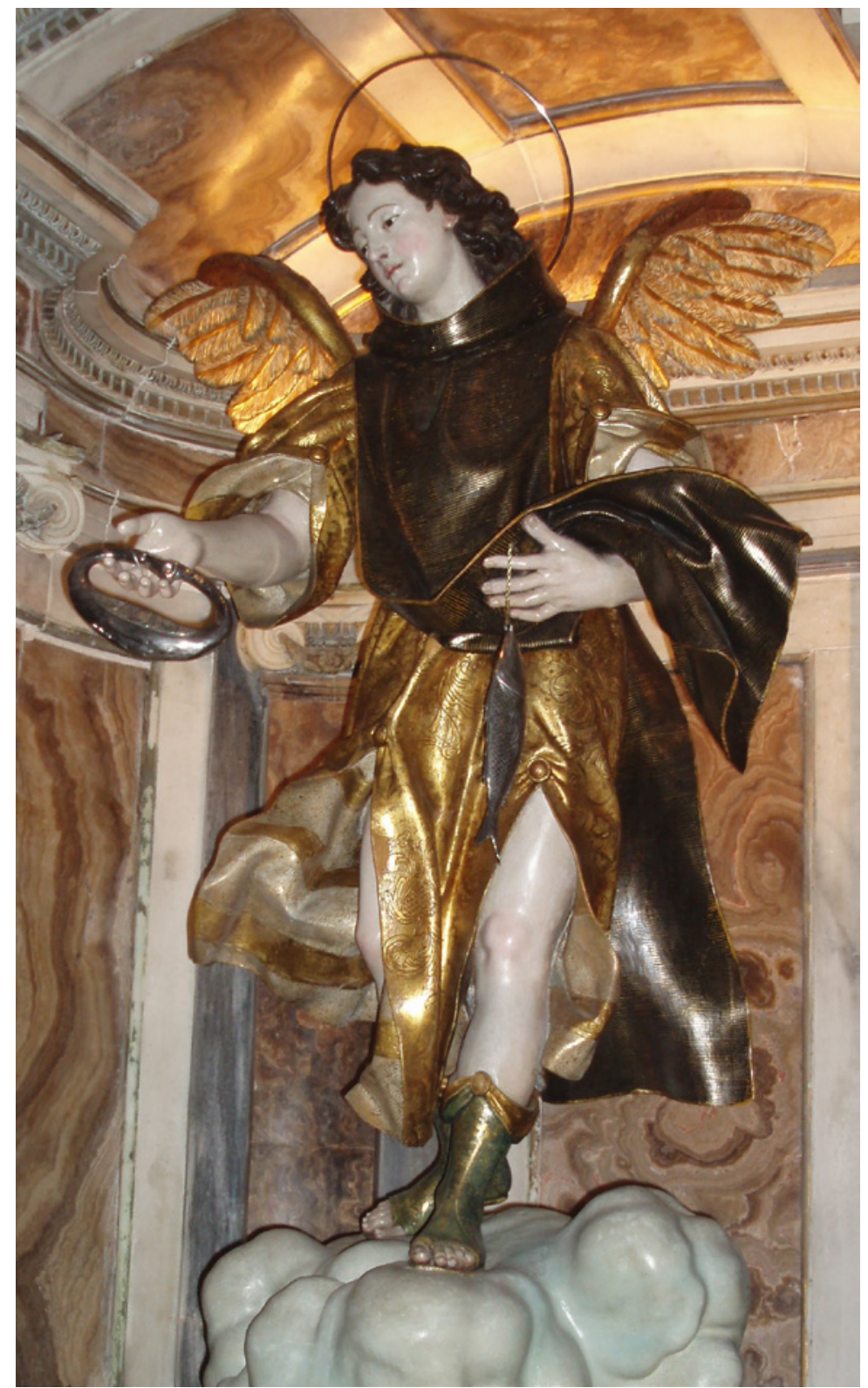

Figura 8. Atribuido a Anton Maria Maragliano: San Rafael Arcángel (1726). Iglesia de San Juan de Dios, Cádiz. Foto: Juan Alejandro Lorenzo. 


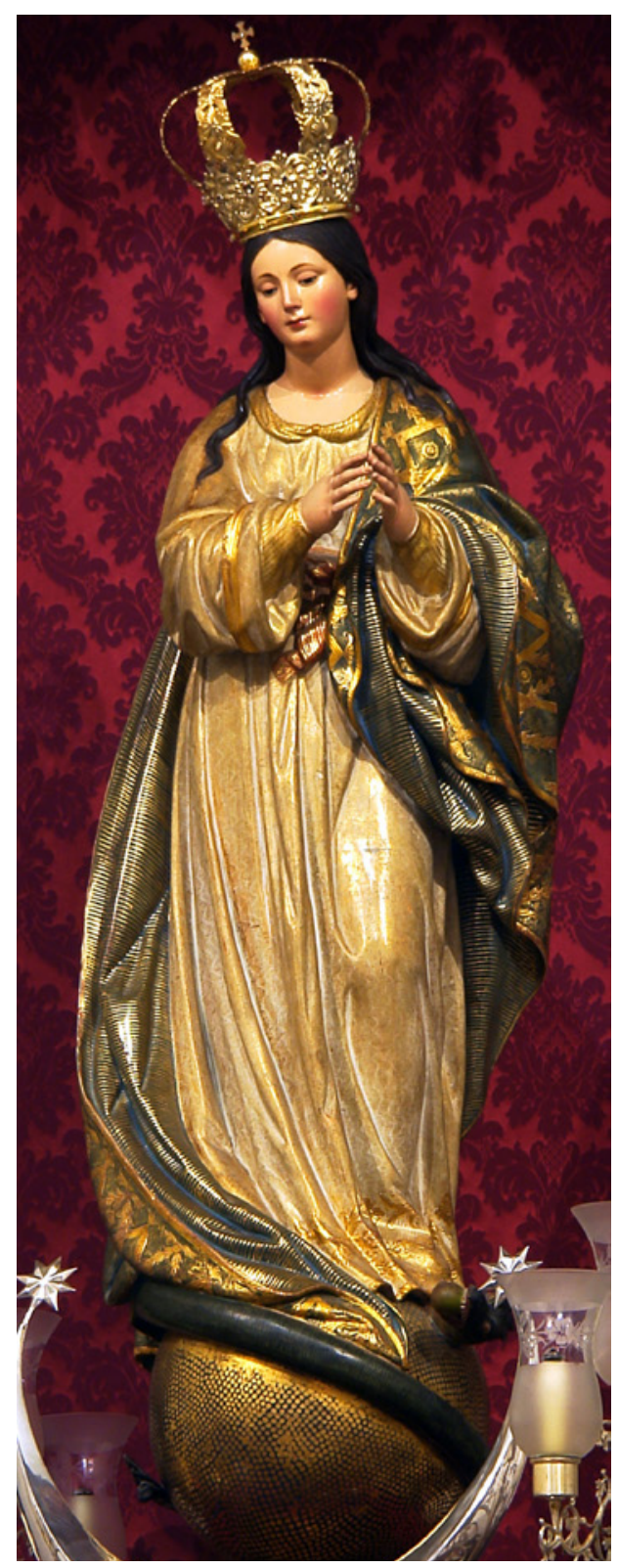

Figura 9. Atribuido a Juan de Astorga: Inmaculada Concepción (1816). Monasterio de monjas concepcionistas, Garachico.

Foto: Josué Hernández. 


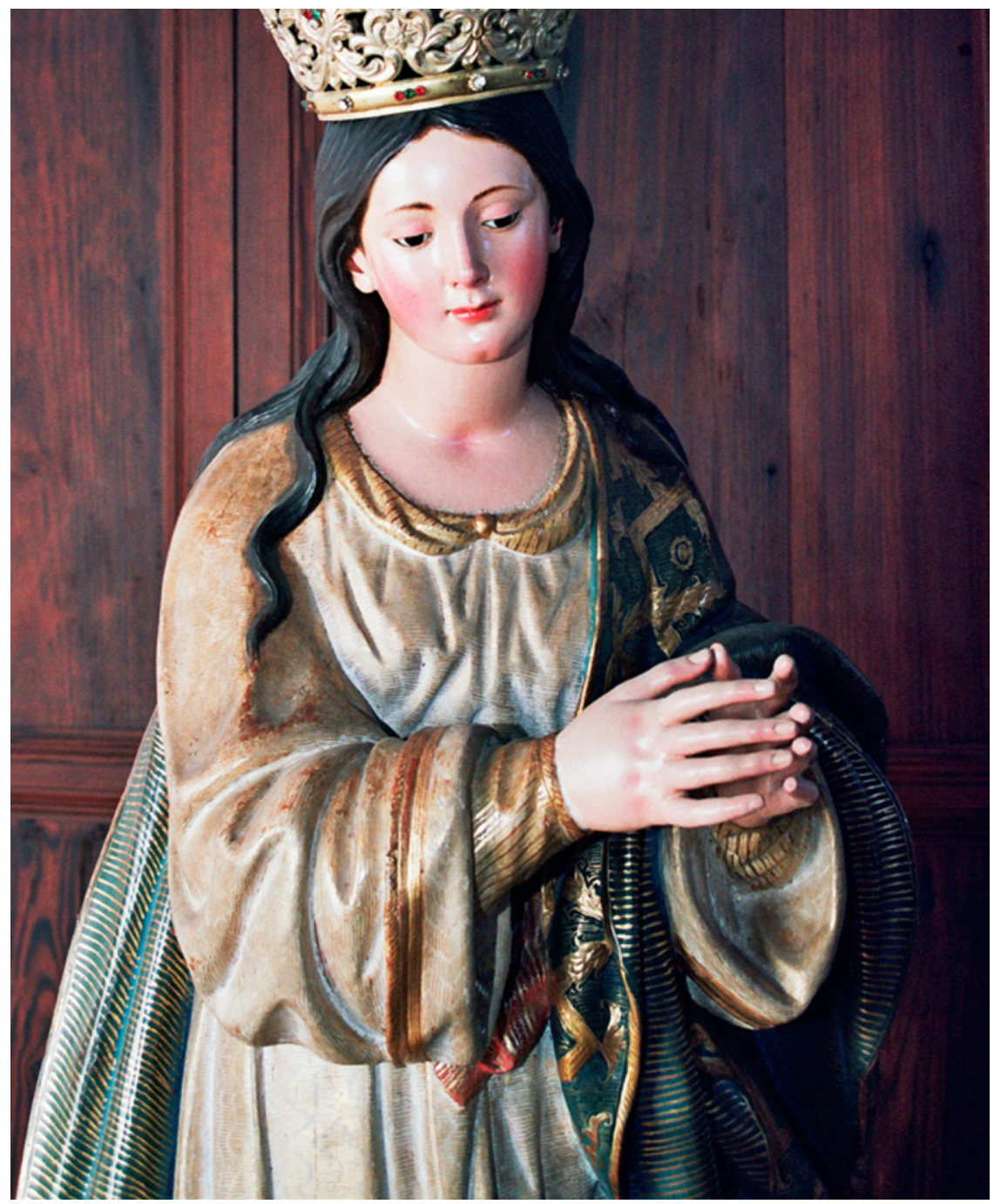

Figura 10. Atribuido a Juan de Astorga: Inmaculada Concepción (1816) [detalle]. Monasterio de monjas concepcionistas, Garachico. Foto: Josué Hernández. 


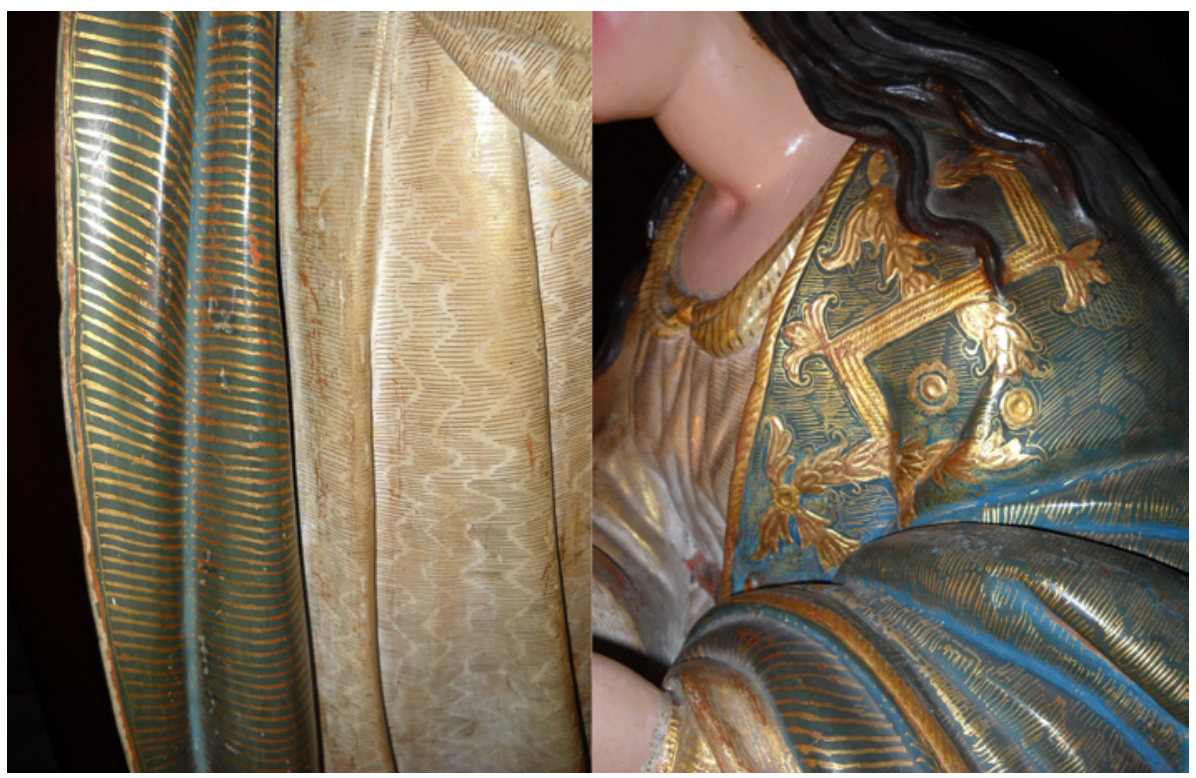

Figura 11. Atribuido a Juan de Astorga: Inmaculada Concepción (1816) [detalles]. Monasterio de monjas concepcionistas, Garachico. Foto: Juan Alejandro Lorenzo. 